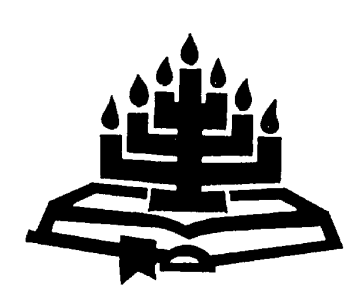

\title{
Hermeneutiek, Schriftgezag en Triniteit ${ }^{1}$
}

\author{
Benjamin Wentsel2 \\ 's-Gravenhage \\ Nederland
}

\section{Abstract \\ Hermeneutics, the authority of Scripture and the Trinity of God}

In order to evaluate a scholarly theological publication any student has to be conversant with the philosophical, confessional and social-contextual suppositions (prejudices, apriori's, the so-called "glasses") forming the background and frame of interpretation as applied by the author. The presence of suppositions is sometimes predominate and clear, sometimes subordinate and hidden. H. Berkhof for instance, applies at least six sets of apriori's in his interpretation of the Bible (see Christelijk geloof - 1973). Underlying the use of these interpretative "glasses" a student has to locate the deepest religious source, the point of departure. Apriori's can, however, be bad and good. The author of this article is convinced of the necessity of applying at least twelve suppositions in the interpretation of the Bible.

In this article the following suppositions will thus be stressed: (1) The Bible is considered as the book of Gods revelation. (2) The fact that the Holy Spirit inspired prophets, apostles, evangelists and collectors (= theopneustia) is supported. (3) The term "Word of God" has a specific meaning as Logos of creation, prophecy, commandment, gospel and so on. (4) The supposition that the Bible is the book of God's covenant implies that the berit is uniting all the different books and all loci of the Christian faith. (5) In order to interpret the Bible in a just way it is necessary to be reborn. (6) The right balance between the value of the Old and the New Testament should be upheld. It should also be confessed that Jahweh (= He is present for us) is the triune God. (7) The normativity of the whole Bible should be acknowledged in relation to the main contours of God's revelation (and not only in isolated texts) and even in relation to changing cultural

\footnotetext{
$1 \quad$ Artikel is redaksioneel versorg deur In die Skriflig.
}

2 Lezing gehouden aan de Teologiese Skool te Potchefstroom op woensdag 17 februari 1999. Dr. Wentsel is oud-docent in dogmatiek aan de Wittenberg, Hogere Beroepsopleiding voor pastorale en missionaire werkers (HBO) te Zeist bij Utrecht. 
circumstances. (8) Reconciliation should be interpreted against the background of the Pésachfeast, the sacrifice-torah and the structure of the covenant. (9) In our interpretation of the Bible we should be on the alert for influences of the devil in opposition to the Holy Spirit. (10) For twenty centuries we have already been members of the Church, the body of Christ. Individualism within the body of Christ can thus imply an underestimation of the work of the Holy Spirit. (11) We remain one Ekklessia and must listen to the interpretation of the Bible by all churches. (12) The Lord is king over all domains and spheres of life. He also reigns over (leaders of) political, educational and societal-structural affairs, as well as over heads of industry.

\section{Inleiding}

Ik ben gedurende de onderzoeken over andere onderwerpen God altijd dankbaar gebleven dat Hij mij door zijn Geest zo beïnvloedde dat ik met de leer aangaande de Heilige Schrift begonnen ben, want heel het christelijk dogma is daarop gegrond. Wankelt de overtuiging dat we in de Heilige Schrift met een gezaghebbend boek te doen hebben, dan wordt heel het christelijk dogma op losse schroeven gezet.

Al studerende leerde ik wat theopneustie is; dat het Woord Gods een gekwalificeerd begrip is; dat dit Woord moet onderscheiden worden van betrouwbare en zondige woorden van mensen; dat de bijbel voor alles een verbondsboek is en dat talrijke auteurs met (dubieus)-gekleurde brillen de Schrift lezen.

Onder "brillen" versta ik apriori's, vooroordelen of - letterlijk vertaald "vantevorenheden" - die zowel van wijsgerige als confessionele aard zijn. Op dit verschijnsel hebben meerderen al gewezen. J.H. van Wyk noemt in zijn Gesindheid en gestalte (1986:186-188) de gevaren van vooringenomenheid, eensydigheid, oppervlakkigheid, individualisme, abstraksie en rasionalisme bij het Schrifberoep. Toen ik klaar was met mijn onderzoek inzake de leer van de bijbel over de bijbel, ging ik na welke apriori's er zoal gehanteerd worden bij het interpreteren van de bijbel. Ik verzamelde ze in Dogmatiek 2, De openbaring, het verbond en de apriori's (Wentsel, 1981). Terwijl H. Bavinck een deel van zijn Dogmatiek wijdde aan de beginselen en filosofische invloeden in de theologie, deed ik iets soortgelijks vanuit de hermeneutiek. Ik onderscheidde tussen goede, minder goede en slechte apriori's. Ik behandelde een aantal apriori's:

- inzake de algemene en bijzondere openbaring,

- inzake het verbond, de oerstaat en de verkiezing,

- inzake theocratie, cultuur en secularisatie,

- inzake Israël en de Islam,

- inzake de Oosters-Orthodoxe en Roomskatholieke Kerk,

- inzake de Lutherse en Gereformeerd-Hervormde traditie, 
- inzake de historisch-kritische richting, Verlichting en de vrijzinnigheid,

- inzake Schleiermacher en Barth,

- inzake de vormgeschiedenis, het Biblicisme, fundamentalisme en het evangelicalisme,

- inzake de politieke theologie en de materialistische exegese.

Ik stelde mij tot taak deze apriori's te analyseren, te beoordelen, de positieve waarden daaruit te honoreren en de eenzijdigheden en de dwalingen daarin in het licht te stellen en te laken. Het is mijn overtuiging dat degene die de apriori's in zijn achterhoofd heeft, vrij snel kan vaststellen met welk soort boek, dat hij onder handen heeft, hij te maken heeft. Wel waarschuw ik hierbij voor een nieuw gevaar: dat van een te snelle en lichtvaardige etikettering; men moet iemand niet in hoek zetten waarin hij beslist niet thuishoort.

\section{De apriori's bij H. Berkhof}

In 1973 verscheen de eerste druk van Christelijk geloof van de Leidse dogmaticus, H. Berkhof (1914-1995), dat in 1993 de zevende druk haalde en dus grote invloed kreeg, althans in Nederland.

Toen ik las dat hij de Godheid van Christus verwierp en daarmee ook de wezenstriniteit, pijnigde ik mijn hersens af over de vraag: hoe kan deze wetenschapper aan de Universiteit van Leiden, dat wetenschappelijk een goede naam heeft, zulke opvattingen exegetisch verantwoorden? Daarom ging ik in Dogmatiek deel 1 (1981) na hoe hij inzake de christologie exegetisch tot dit resultaat gekomen was.

Tevens zag ik mij daarbij genoopt inzake de christologie een ander antwoord hierop te geven dan hij deed. Dit was de eerste reden dat ik - tegen de traditie in - in deel een tegelijkertijd behandelde de Heilige Schrift en de persoon van Christus. De tweede reden was dat in het Nieuwe Testament Jezus zelf en de verkondiging aangaande Hem Logos wordt genoemd.

Het bleek mij dat Berkhof's apriori's voornamelijk zes in aantal waren.

- Het eerste apriori noem ik de talmoedische bril. Volgens de talmoedische interpretatie van het Oude Testament is de Messias niet de met God wezensgelijke Zoon maar een profeet of telg uit Davids geslacht, brenger van het Rijk Gods. In hellenistisch-joodse kringen werd de wijsheid gepersonifiëerd of als preëxistent bestaande beschouwd - vergelijk Spreuken 8. Dit zou er in joodschristelijke kringen aanleiding toe hebben gegeven om Jezus te vergoddelijken.

- Het tweede apriori noem ik de dominant oud-testamentische bril. Hieronder versta ik de methode om het Nieuwe Testament eenzijdig of uitsluitend te 
verklaren vanuit het Oude Testament. Ik noem daarvan een voorbeeld. In Exodus 4:22 wordt Israël Gods eerstgeboren zoon genoemd; in Psalm 89:2138 worden David en zijn zonen zonen van Jahweh genoemd in theocratische zin. Welnu, in Matteus 2:15 worden Exodus 4:22 en vooral Hosea 11:1 ("uit Egypte heb Ik mijn zoon geroepen") op de naar Egypte gevluchte Jezus toegepast. Dus leidt men hieruit af dat wie in de achteruitkijkspiegel van het oude verbond kijkt, Jezus' persoon dient te interpreteren als een gezalfde of koning of volmaakte verbondsmens maar niet als de enige, preëxistente Zoon des Vaders in wezensgelijke (homo-ousiaanse ) zin. Dit kan ook niet - zo poneert men dan - omdat het Oude Testament de eenheid van God kent. Dan kan er geen "tweede" bijkomen.

- Het derde apriori bij Berkhof is het lezen van de bijbel met de bril van de historisch-kritische methode. Volgens deze uit de tijd van de $18 \mathrm{e}$ eeuw, het tijdperk der Verlichting afkomstige methode moet bij ieder bijbelgedeelte de echtheid onderzocht, vastgesteld of afgewezen worden, en nagegaan worden welke groep gemeenten of welke apostel of welke evangelist zijn subjectief stempel op een bepaald gedeelte heeft gedrukt. De gezagswaarde van diverse stukken wordt ook volgens een bepaald schema vastgesteld.

In dit kader komen we de opvatting tegen dat christenen uit hellenistische kringen, die helden of keizers tot godenzonen of kurioi uitriepen, Jezus met een goddelijk aureool omgeven zouden hebben. De christelijke Kerk in de eerste eeuw zou zich door deze stroming hebben laten beïnvloeden. Als nalatenschap van het christendom zou verklaard moeten worden dat Nicea325 beleed: "God uit God, Licht uit Licht, waarachtig God uit waarachtig God, niet geschapen, eens-wezens (homo-ousion, consubstantialem) met de Vader, en door Wie alles geworden is". 3

- Een vierde apriori bij Berkhof is een getransformeerde Barth-bril. Uitgaande van het christocentrisme stelt hij dat Christus doel is van de schepping. Vervolgens laat hij wel - contra Barth - de Godheid van Christus vallen, maar buigt hij diens christocentrisme om in deze zin dat alle openbaring blijk geeft van Gods genade. Dit heeft dan bij hem tot resultaat dat God zich in de nietchristelijke godsdiensten op een vage, schemerachtige wijze, en in Christus op een duidelijke, manifeste wijze openbaart. Christus is dus norm maar geen exclusieve Godsopenbaring. maar eveneens op onze hoede moeten zijn voor de rationalistische hyperkritiek en (groeps)subjectivistische willekeur. Het intellectueel clericalisme wil graag de dienst uitmaken inzake wat nog wel of niet houdbaar is in de bijbel en stelt zich vaak op dwars tegenover het kerkelijk belijden met als pretentie dat allerlei opvattingen "achterhaald" zijn. 
- Als vijfde apriori noem ik de a-metafysische of anti-metafysische bril. Daaronder versta ik de tendens om het spreken over God in zichzelf af te wijzen en alleen over Hem te willen spreken vanuit zijn scheppings- en heilsopenbaring. Hierbij behoort een zekere huiver voor deugden als zijn almacht, alomtegenwoordigheid, alziendheid enzovoort.

- Als zesde vooroordeel noem ik de genadetriomfbril. God is wel de Heilige die de verharde zondaar straft, maar zijn barmhartigheid is groter dan zijn toorn, terwijl er ook in het hiernamaals bekeringskansen zijn; eens komt er een einde aan de hel, zodat ieder zalig wordt. Berkhof hoopt dus op een alverzoening, een ketterij die ook de christen-wijsgeer Origenes verdedigde vanuit zijn gnostieke inslag ("alles keert weer terug tot zijn oorsprong"). De genade wint het van het oordeel: "alles sal recht kom".

Ik noem deze zes brillen - die met anderen te vermeerderen zijn - als illustratie van de wijze waarop in bepaalde kringen vanuit bepaalde standaarden (apriori's) getheologiseerd wordt. Wie naïef - d.w.z. zonder kennis genomen te hebben van de achtergronden en methodes en vooroordelen - zulke boeken leest, komt daarvan onder de indruk, zeker als deze ook nog vlot en populair geschreven zijn en de eigen tijdgeest tegemoet komen. Verschillenden van mijn studenten in Zeist vonden Berkhof's Christelijk geloof dan ook een mooi boek. Ze misten de goede kritische leesbril om een juist oordeel daarover te vellen. Ze werden meegenomen in een theologie waarin de Godheid van Jezus sneuvelde en daarmee ook de Drieëenheid, hoewel de naam werd gehandhaafd.

\section{De populariteitsoorzaken}

Soortgelijke lees- en interpretatie-brillen vinden we ook terug bij wijlen E. Flesseman van Leer, een christen-jodin, wereldraadtheologe, bij H.M. Kuitert, emeritus-hoogleraar ethiek VU, bij C.J. den Heyer, Nieuw-testamenticus in Kampen en bij S. Schoon, docent in Kampen en bij de roomskatholieke Hans Küng, als hoogleraar bij de RK faculteit afgezet, in de oecumenische sektor gehandhaafd, bij de roomskatholieke dichter en pastor Huib Oosterhuis, die een eigen dissident-katholieke groep leidt maar zeer populair is bij vele roomskatholieken en protestanten, en bij de protestantse Oudtestamenticus en dogmaticus HansJoachim Kraus, die in 1975 een dogmatiek schreef onder de titel Reich Gottes: Reich der Freiheit. Grundriss Systematischer Theologie, 1975.

De populariteit en invloed van H. Berkhof, Kuitert en Den Heyer wier boeken vele drukken in meerdere talen beleven, verklaar ik uit een vijftal factoren.

- Ten eerste stammen zij uit een orthodox-protestants milieu en schoven zij vandaar op naar de vrijzinnigheid. Velen zijn nieuwsgierig naar de wijze waarop en motivatie waardoor zij deze zwenking voltrokken. 
- In de tweede plaats spreken zij een laag mensen zoals zoekers en van de kerk vervreemden aan. Zij hebben ook heelwat aanhang onder theologen, zij het op afstand. In West-Europa is er grote belangstelling voor religieuze boeken, vooral voor die welke afwijken van het normale dogmatisch-kerkelijke patroon. God blijft ook in de literatuur onderwerp van gesprek zoals bijvoorbeeld in Harry Mulisch's De ontdekking van de hemel (1992), dat al meer dan 23 drukken beleefde en in circa 200.000 exemplaren verspreid werd.

- Ten derde bekleden zij een universitaire positie. De tendens is om wat van de "academie" komt, hoog te waarderen als progressief, toekomstgericht en waar. Later volgt de ambtelijke kerk deze geavanceerde kopgroep dan wel, suggereert menigeen.

- Ten vierde kampt het Westen met een onverwerkt complex van schuld inzake de vernietiging van zes miljoen joden. Terwijl de Nederlandse bisschoppen duidelijk de schuld van de Roomskatholieke kerk beleden, kon het Vaticaan tot een royale schuldbelijdenis nog niet komen. Uit dit verdrongen schuldbesef verklaar ik ook de tendens dat meerdere theologen menen dat de Kerk zich moet aanpassen aan de talmoedische theologie, die volgens hen het beste het Oude Testament kan verklaren.

- Een vijfde factor kan zijn dat de orthodoxie traag reageert op en niet voldoende inhaakt op de huidige vraagstukken in de mening dat in de bestaande confessies voldoende pasklare antwoorden gegeven zijn. Daar de gezagswaarde van de confessies in het geding is, blijft het m.i. noodzakelijk om vooral - niet alleen - vanuit de bijbel aan te tonen welke antwoorden gegeven moeten worden.

Bij alle apriori's geldt dat wij tot de diepste bodem - die altijd van religieuse aard is - moeten doorstoten. Het hart van de wetenschapper kan onbekeerd zijn en zich ergeren aan de Rots (= de Heilige, Christus) of rotsen zoals het kruis der verzoening of de uitverkiezing. We stuiten dan op het harde hart of op verharde gedeelten van het bekeerde hart (het skandalon). Dit betekent dat rondom en vanuit het ongeloof of verzet tegen God als kern en haardvuur argumenten contra het christelijk dogma worden aangevoerd, die ontleed moeten worden als exponent van dit verzet tegen de Rots en als quasi-wetenschappelijk weerlegd dienen te worden.

\section{De juiste apriori's of heldere brillen}

Hier denken wij aan de bijbel als openbaringsboek, de bijbel als Geestesboek, als Woord Gods, als verbondsboek, de wedergeboorte 
Welke zijn de heldere brillen om de bijbel zo goed mogelijk te lezen? Iedere theoloog is verplicht zich rekenschap te geven van zijn uitgangspunt. Wat is voor Hem de bijbel? De Kerk der eeuwen heeft geleerd dat de theopneuste Schriften norm zijn voor leer en leven. In de loop van de eeuwen hebben zich dan ook goede uitgangspunten gevormd, ware apriori's. Ik noem daarvan de voornaamste; er zijn er meer te noemen.

\subsection{De bijbelboeken zijn de neerslag van Gods openbaring}

Een eerste juiste apriori is dat de bijbelboeken de neerslag zijn van Gods openbaring. Mensen hebben de feiten en hun interpretatie niet uitgedacht. De boeken komen van boven en niet van beneden zoals ook Christus van boven uit de hemel komt en ons verkondigt wat Hij heeft gezien en zoals ook de Heilige Geest door de Zoon als Kurios uit de hemel op aarde is gezonden. Ik bestrijd hiermee de mening dat de boeken van de bijbel in de eerste plaats exponenten zouden zijn van subjectieve of subjectivistische ervaringen ("projecties"). Dit subjectieve element zit er ook in (vgl. de Psalmen) maar is niet beslissend of dominerend.

\subsection{Theophneustie der Heilige Geest}

Een tweede apriori is dat de Heilige Geest verkondigende profeten, boekenbewarende priesters, onze Here Christus, zijn apostelen, evangelisten en apostolische figuren heeft beïnvloed, geleid, geheiligd en geïnspireerd of - met een betere term - getheopneustiseerd. De theopneustie van de bijbel als collectie boeken is door het rationalisme sterk aangevochten, ja als onzinnig verworpen maar de Kerk der eeuwen - ook de Roomskatholieke Kerk van Vaticanum II belijdt deze volkomen terecht. We vinden de theopneustieleer bij de rabbijnen, tijdgenoten van onze Heer, bij Hem zelf krachtens zijn beroep op het Oude Testament (hè grafè, gegraptai), bij de apostel Paulus ("de heilige Schriften") en andere apostelen. Het gezag van deze Meester en zijn speciaal door Hem geroepen en toegeruste knechten dient voor Kerk en wetenschap beslissende betekenis te hebben. We vinden de theopneustieleer terug in de kerkgeschiedenis terug bij Calvijn, H. Bavinck, K. Rahner, G.C. Berkouwer, J.A. Heyns (1978:1735), J.H. van Wyk (1989) en vele anderen.

We kunnen het inspiratiegebeuren, een lang proces van Gods ademstoten, vergelijken met een begietingsinstallatie met buizen en met openingen daarin waardoor het water wordt geperst om de planten te bevochtigen. De profeten en apostelen ontvingen de Geest Gods, vervolgens de teboekstellers van de profetieën en evangeliën, daarna ook de collectors. Dit pneumatisch proces gaat actueel op andere wijze door omdat de Heilige Geest als eerste auteur de lezer, het boek en de verkondiger daarvan in een onderlinge wisselwerking blijft 
beademen. Om een goed verkondiger te kunnen zijn, blijft het voor een theoloog nodig zijn hebreeuws en grieks bij te houden en de bijbel te blijven bestuderen.

\subsection{Wij hebben een goed inzicht in het karakter van het Woord Gods}

Woord Gods is in de bijbel het Woord van de schepping en het onderhouding ervan, van het gebod, van het heil, van de bedreiging, van det daadwerkelijke verlossing, van het effectief voltrokken gericht, als de Zoon als de Logos die God was en is, als het verkondigde evangelie (vooral bij Lucas). Dit Woord is onfeilbaar. We dienen op grond van de bijbel onderscheid te maken tussen het rechtstreekse Woord van God tot en door profeten, Christus en apostelen enerzijds en de reacties van mensen daarop anderzijds: ware woorden, zondige, zelfs door de duivel geademde boze woorden. Bij dit laatste past meer de kwalificatie: betrouwbaar.

\subsection{De bijbelboeken zijn verbondsgeschriften van de Getrouwe voor zijn volk}

De zeer uiteenlopende cahiers zijn gebundeld rondom een spiraal: het verbond van Jahweh met Abraham (Gen. 17), voortgezet in het verbond op de Sinaï, in beginsel voleindigd met de uitstorting van de Heilige Geest. Zonder deze bindingsspiraal zou de bijbel een collectie van min of meer onsamenhangende geschriften of losse blaadjes zijn. Vele exegeten beklemtonen - terecht - het eigene van iedere auteur, maar zij zien niet voldoende of soms helemaal niet in dat Hij-Is-Er-Bij (=Jhweh), de Ene verbondsgod, en zijn Enige, zoon van Abraham en David, alle auteurs en hun geschriften verenigt. Men zegt dus te weinig, indien men zich beperkt tot de uitspraak: de Schriften zijn theopneust! We dienen aan iedere auteur en ieder geschrift afzonderlijk recht te doen en mogen geen dogmatische, laat staan dogmatistische of gedwongen-harmoniserende exegese bedrijven maar we dienen wel rekening te houden met het verbondskarakter van de Geschriften van de Heilige.

Zelf ontdekte ik van welk een zwaargewicht de verbondsleer is, toen ik studeerde voor Dogmatiek 3A: Godsleer, mensleer en zondeleer (1987). Ik wijdde daarin aan het verbond een heel hoofdstuk (203-254). In alle loci krijgen we met het verbond te maken. Wie het verbond met zijn twee of drie polen kent, krijgt ook een diep inzicht in de structuur van de verzoening als een totaal proces van herstel (de kat-allagè - "reconciliation") van Gods kant, als het werk van de zoening (hilasmos) van Jezus naar God en ons toe, en als deelname van ons daaraan als nieuwe schepselen met ons schuldbesef, geloof, rechtsherstel (satisfactie) en opstanding uit de doden. Hij gaat ook zien de effecten van Gods zegen en bedreiging in heil en gericht in de geschiedenis van Israël en de kerk 
krijgt inzicht in het teken van de besnijdenis en de doop, Pèsach en het Nagmaal (Wentsel, 1998b).

\subsection{Wedergeboorte als voorvereiste}

Alleen de wedergeboren theoloog heeft de adequaat-verlichte ogen om de bijbel goed te kunnen lezen en te verklaren. De Schriftkenner-parlementariër Nikodemus treedt namens de theologen-leiders Jezus met een grote welwillendheid tegemoet: "Ons weet dat U 'n leraar is wat van God gekom het", maar onze Kurios stelt zijn geleerde gesprekspartner totaal in gebreke: "Voorwaar, voorwaar Ek sê vir jou, als iemand nie opnuut gebore word nie, kan hy die koninkryk van God nie sien nie" (Joh. 3:2-3).

Dus moeten hoofd en hart de invloed van Gods verlichtende Geest ondergaan hebben om Jezus' identiteit te onderkennen, de Schriften goed te kunnen uitleggen en het rijk Gods binnen te gaan. Hierbij wil ik enige misverstanden afsnijden.

- Wie uit Gods liefde herboren is, kan daarmee nog niet volstrekt gaaf exegetiseren. Hij heeft ook de technisch-hermeneutische kennis nodig evenals de voortgaande verlichting van de Heilige Geest, terwijl er bovendien allerlei teksten raadsels blijven bevatten.

- Een niet-wedergeboren theoloog kan vooral filologisch uitstekende resultaten boeken, waarvan wij de vruchten kunnen plukken, maar kan de uitlegger ook op een verkeerd spoor zetten.

We stuiten hier op vele problemen, ook in kerkrechtelijk opzicht. Wat is de wetenschappelijke waarde van die veel verkochte boeken van hen die hun ongeloofsapriori duidelijk belijden: "ik geloof niet meer in waarheden als de Triniteit en de verzoening"? Zijn zulke theologen niet bezig het christendom te veilen op de markt of kernwaarheden als vuil aan de kant te zetten voor de vuilnisophaaldienst? Welke gezagspositie hebben docenten in een kerkelijke gemeenschap als zij met het dogma niet meer overweg kunnen? Is het niet veel eerlijker dat zij zelf ontslag nemen of dat zij uit hun ambt verwijderd worden? Kan er een dualisme bestaan tussen universiteit en Kerk?

Wie ontkent dat de profeten als Gods gezondenen, Jezus en de apostelen alles van Boven kregen, mist een zintuig, heeft een oppervlakkige bril op en zal tot verkeerde resultaten komen. De biddende studerende predikanten krijgen de preken nog steeds van boven! De diepe samenhangen worden zonder Gods Geest niet doorzien. Iemand werp tegen: "Wie maakt uit welke exegeet Gods Geest heeft?" Ik antwoord daarop: "Beproeft de pneumata, de auteurs, of zij uit God zijn, of zij Jezus als met de Vader wezensgelijke Zoon erkennen!" 


\subsection{De verhouding van het Oude Testament tot het Nieuwe Testament en de Triniteitsleer}

Als zesde apriori noem ik de evenwichtige benadering van het Oude en Nieuwe Testament in hun onderlinge verhouding en in verband daarmee ook de Triniteitsleer. We zijn gedoopt in de Naam van God de Vader, God de Zoon en God de Heilige Geest. De Ene van het Oude Testament is ook de (Drie)-Ene van het Nieuwe Testament. We mogen teruggaan van het Nieuwe naar het Oude en vooruitgaan van het Oude naar het Nieuwe. Het Nieuwe is in het Oude verborgen (latet), het Oude gaat in het Nieuwe open (patet).

In een Open brief heb ik (zie Zcheltens \& Wentsel, 1998) de opvattingen van enige theologen, ook van H.M. Kuitert in zijn Jezus, nalatenschap van het christendom (1998), inzake het God-zijn van Christus en de Triniteit bestreden. Zij beriepen zich met name op de eenheid Gods in het Oude Testament als norm voor het Nieuwe. Ik stelde daarom opnieuw aan de orde het "Schriftbewijs" inzake de Triniteit in het Oude Testament. Ik had dit al behandeld in Dogmatiek $3 A$ (1987:299-392), maar thans voerde ik als argument aan de zelfbetiteling Gods als God-van-Abraham, God-van-Izak en God-van-Jakob (afgekort als ElABIJAK). Ik noemde dit een voorafschaduwing en analogie van de Drieeenheid. Abraham, de eerste patriarch, heet de vader der gelovigen, hetgeen correspondeert met God de Vader, de eerste in de orde van het Godsbestaan. Izak, de tweede patriarch, de enige zoon die door zijn vader geofferd wordt, wijst heen naar Jezus, de eniggeborene van de Vader, die Hem offert op Golgotha. En Jakob, de derde in de orde van de patriarchen, die tweemaal Beth-El als Gods gemeenschap beleeft en stichter van de twaalf stammen is, wijst heen naar de Heilige Geest, de derde Persoon, die tot specifieke eigenschap heeft de gemeenschapsstichting (koinonia) en de Kerk der twaalf apostelen sticht.

Op deze suggestie - één in drie, drie in één, ieder met eigen functie, altijd Abraham de eerste in de orde van drieheid - kan men wel het een en ander afdingen; zo kan iemand tegenwerpen: "Alle drie patriarchen waren vaders". Afkerig van speculaties sprak ik bewust van een voorafschaduwing. Waarom lopen meerdere theologen storm als het Oude Testament vanuit het Nieuwe Testament wordt verklaard en als er een parallel getrokken wordt tussen ElABIJAK en de Triniteit? Wat zit daarachter? Gelooft men eigenlijk niet in de Drie-Enige? Heeft men alleen maar een intellectueel lesje geleerd en niet verwerkt dat onze God in zichzelf van eeuwigheid een Gemeenschap is en er niet alleen een openbarings- maar ook een Wezenstriniteit is en de eerste de exponent is van de laatste? Geeft de orthodoxie daarom zo gemakkelijk belijdenissen prijs omdat men de waarheid daarvan nooit verwerkt heeft? Natuurlijk is Jahweh, de God van het Oude Testament, ook in het Oude Testament trinitarisch zoals Hij ook Jahweh de Ene blijft in het Nieuwe Testament. Als iemand geen genoegen neemt met de naam El-ABIJAK als analogie wijs ik hem terloops ook nog op het 
feit dat Jahweh beurtelings onderscheiden wordt van de Engel-des-HEREN en vervolgens met Hem wordt vereenzelvigd - vergelijk Exodus 3-4 en Richters 6, maar het is bekend dat dit argument voor velen evenmin beslissend is als bewijs voor de Triniteitsleer in het Oude Testament.

Ik houd staande: de Drieëenheid is geen uitvinding van de Grieken of Hellenisten of de christenen of Athanasius of de Cappodociërs of de Kerk van de eerste eeuwen! God is van eeuwigheid, in zichzelf Vader. Hij heeft altijd, voor de menswording van de Zoon, een Zoon gehad. De Zoon is van eeuwigheid zijn "Tegenover". Wie zegt: "God is liefde" zegt daarmee ook dat Hij van eeuwigheid een Ander tegenover zich moet hebben gehad om lief te hebben. De Geest waait eeuwig uit de Vader naar de Zoon en van de Zoon tot de Vader. God is in zichzelf gemeenschap.

Hoe belangrijk deze Drie-eenheid is, blijkt ook uit de identiteit van de kerk als één saamhorige gemeenschap, waarin Hij zich weerspiegelt. Onze Heer heeft dat aangrijpende gebed om eenheid gebeden in Johannes 17:19-23 om ons diep te doordringen van de werkelijkheid dat allen die Hem belijden één gemeenschap vormen (moeten) en door die eenheid en saamhorigheid de buitenwereld moeten aantrekken!

"Maar Ek bid nie vir hulle alleen nie, maar ook vir die wat deur hulle woord in My zal glo - dat almal een mag wees net soos U, Vader, in My en Ek in U, - dat hulle ook in Ons een mag wees, sodat die wereld kan glo dat U My gestuur het" ( Joh. 17:20-21).

Diep triest is het dat er zo'n 600 of meer presbyteriaanse of gereformeerde kerken als gescheiden eenheden bestaan. Deze verdeeldheid is een anti-reclame en obstakel voor de niet-kerk om Jezus als gezondene van de Vader te erkennen. Het is voor Die Gereformeerde Kerke in Suid-Afrika een dringende opdracht om institutionele structuren te vinden om zwarten, kleurlingen en blanken te verenigen. Er kunnen gemeenten groeien waarvan alle drie categorieën lid zijn. We kunnen niemand tot eenheid dwingen, maar onze Heer heeft daarvoor zo dringend gebeden dat we daaronder niet uit kunnen. Binnen een bepaalde institutionele structuur kunnen afzonderlijke eenheden blijven bestaan. In de Samen-op-weg-Kerk (VPKN = Verenigde Protestantse Kerk in Nederland) behouden de Luthersen het recht om een eigen synode te houden omdat er in de wereld ongeveer 50 miljoen Luthersen zijn met wie zij in contact blijven, maar dit geschiedt binnen de gemeenschappelijke Synode.

Onze liefde voor elkaar weerspiegelt de liefdevolle eenheid van de Vader en de Zoon voor elkaar door de Heilige Geest in ons. Dat moet in iedere kerkdienst en in ieder gesprek tot uitdrukking komen, ook in de dialoog tussen theologen. De 
vlam der liefde, door de Geest in ons ontstoken, dient ons tot elkaar te trekken. Als we de bijbel recht interpreteren, dan komen wij op alle mogelijke manieren, ja in alle loci's, van schepping tot voleinding, van ecclesiologie tot de pneumatologie deze Drie in de Ene en deze Ene in de Drie tegen. Hebben de diverse soorten gereformeerden of presbyterianen voldoende beseft welke consequenties de Drieëenheid heeft voor de ecclesiologie? In de gereformeerde hermeneutiek is terecht veel aandacht geschonken aan de bijbel als Heilige Schrift, maar men heeft niet voldoende ingezien dat, overal waar de drie-enige God beleden wordt, de Kerk aanwezig is.

\subsection{Gods geopenbaarde wil wordt verbonden met de culturele context}

Deze apriori sluit in normativiteit en contextualiteit, verzoening, daemonen, sociale gemeenschap, eenheid, Gods koningschap over het gehele leven. De wijze waarop Gods geopenbaarde wil met de culturele context verbonden wordt is een uiterst gevoelig en belangrijk apriori (apriori seven). Ik neem als voorbeeld de positie van de vrouw. In de bijbel lopen twee hoofdlijnen. De eerste hoofdlijn is dat man en vrouw gelijkwaardig zijn. Beiden zijn geschapen naar Gods beeld (Gen. 1:26-28) (Wentsel, 1987:592-597; 627-644). Beiden zijn in Christus herschapen kinderen Gods (Gal. 3:26-28). Beiden ontvangen de Heilige Geest gelijkelijk (Hand. 2:17-21). Derhalve zijn vrouwen mondige dragers van de Heilige Geest in alle sektoren van de maatschappij en volwaardige kerkleden, ook inzake het ambt. De tweede hoofdlijn is dat man en vrouw ongelijk zijn. Deze ongelijkheid komt uit in de wijze waarop man en vrouw zich gedragen en keuzes maken. Het blijkt dat meerdere vrouwelijke predikanten een voorkeur vertonen voor de "zachte" sektor in het predikantenbestaan: het begeleiden van zieken of bejaarden. De kwestie van de vrouw in het ambt mag dus niet beslist worden vanuit één tekst, maar dient beslist te worden vanuit de grondlijnen van de bijbel. En daarin dienen ook de culturele verschuivingen betrokken te worden inzake de positie van de vrouw. Zo brak de Kerk in Handelingen 15 met het gebod dat iedereen besneden moest worden. Dit werd voor bekeerde heidenen niet meer verplicht gesteld. Een van de eigenaardigheden van het fundamentalisme is dat het moeite heeft met historische breuken en stroomversnellingen en dat het losse teksten als kapstok voor eigen apriori's gebruikt. We dienen het gezag van de bijbel volledig te honoreren maar op verantwoorde wijze! 


\subsection{De verzoening wordt vertolk vanuit de struktuur van het verbond en het offerleer}

Een achtste gaaf apriori is dat de verzoening vertolkt wordt vanuit de structuur van het verbond en de offerleer in Exodus (Pèsach) en Leviticus (Hebreeën) ${ }^{4}$.

\subsection{Wij houden rekening met de werking van boze geesten}

Een negende apriori is dat wij te allen tijde en op alle gebieden, ook in de theologische arbeid, rekening houden met de werking van boze geesten contra die van de Heilige Geest (Wentsel, 1987:666-714). Onze Heer gaat in de woestijn aanstonds een tekstenduel aan met de valse hermeneut-bijbelkenner Satan (Matt. 4:1-11). "En die Seun van God het juis gekom om die werk van die duiwel tot niet te maak" (1 Joh. 3:7). Het rationalisme schafte de duivel af met als triest gevolg dat heel wat theologen het rechte spoor bijster raakten en zijn instrument werden in het zaaien van twijfel en ongeloof! Maar ook zij die theoretisch wel in het bestaan van demonen geloven, houden niet altijd genoeg rekening met de invloed van boze geesten in nijd en jaloersheid in hun (on)collegiale omgang, schismatieke neigingen in de kerk, tyrannieke driften in hun polemiek!

\subsection{Wij zijn lid van de kerk als lichaam van Chirstus}

Een tiende gaaf apriori is dat wij als kerkleden en wetenschappers ons bewust zijn dat wij lid zijn van de kerk als het lichaam van Christus en als sociale gemeenschap en dat wij geloven dat de Heilige Geest de Kerk al twintig eeuwen in de waarheid heeft geleid. Alle individualisme zij ons daarom vreemd. De theoloog die solistisch meent geheel opnieuw te kunnen beginnen, bedroeft de Heilige Geest. Dit betekent dat wij aan credo's en confessies als werk van de Heilige Geest in vorige generaties een hoge waarde toekennen, al dienen we ook rekening te houden met het contextuele ontstaan daarvan. Het confessionalisme moge fundamentalistische trekken hebben - ahistorisme - de liberale theologie is individualistisch en autonomistisch en doet beslist te kort aan het werk van de Geest der waarheid in 20/21 eeuwen.

\subsection{Er bestaat slechts één Ekklesia}

Een elfde juist apriori is dat wij in ons kerklidmaatschap er rekening mee houden dat er volgens het eenparig getuigenis van het Nieuwe Testament slechts één Ecclesia bestaat. Bij iedere afzonderlijke kerk - met kleine letter - dienen we te bedenken: ook die andere kerk is een deel van Christus' Kerk, het gaat om Zijn en om onze zaak: tua res agitur. Kerkisme is een vals apriori. 


\subsection{Jahwe is koning over de gehele aarde}

Een twaalfde alomgeldig apriori is dat Jahweh koning is over de gehele aarde en dat Hij zijn heerschappij uitoefent door Jezus, zijn eniggeboren Zoon die Hij heeft aangesteld tot soevereine Kurios over kerk en wereld. Dit betekent dat wij de heerschappij van Christus tot uiting brengen in de sektor van het persoonlijk leven, in het gezinsleven, in het kerkelijk leven, in het maatschappelijk-politieke leven en in de school/universiteit. De kloof tussen arm en rijk dient vanuit het Koningschap van Christus overwonnen te worden. De wetenschap en de vrezedes-Heren horen bij elkaar. Het uitoefenen van tyrannie van de ene groep over de andere stemt niet overeen met Jezus' heerschappijvoering door Woord en Geest. In zijn The last trek (1998:191-192) stelt F.W. de Klerk dat het achteraf beter was geweest als de Nationale partij de breuk met de apartheid tot uitdrukking had gebracht door een totale naamsverandering. Zou het niet beter geweest zijn dat deze partij geheel opgeheven werd vanwege het belaste verleden? Een christelijkpolitieke partij dient de Naam en het Rijk van God liefde en gerechtigheid tot uitgangspunt te nemen. Het Christen Democratisch Appèl in Nederland (= een unie van KVP, AR en $\mathrm{CHU}$ ) is te waterig - helaas - maar men kan van de weeromstuit ook in fundamentalistische wateren verzeild raken. Wellicht zitten er mogelijkheden in een verbreding van de ACDP. De kern is: we mogen - als wereldvreemd piëtisme - de heerschappij van onze Koning niet beperken tot de "ziel" en evenmin tot het "instituut van de Kerk".

Er zijn meer apriori's te noemen die de bijbelse boodschap grondig weerspiegelen en goede leesbrillen zijn geworden bij het lezen van de bijbel zoals er ook reducerende en scheefzinnige brillen zijn. Ik volsta hiermee en verwijs verder naar mijn Dogmatiek deel 2 (1982).

Moge het onze Koning Christus behagen door zijn Geest en Woord het Rijk van liefde en gerechtigheid zo te brengen in Zuid-Afrika dat aan alle volken en groepen recht wordt gedaan en aan het moorden een einde komt. De getuigende en voor de overheid biddende kerken kunnen hierin een belangrijke gewetensvolle rol spelen.

U, Vader, Zoon en Heilige Geest zij de heerschappij en de lof nu en altijd in millennium millenniorum!

\section{Literatuur}

BERKHOF, H. 1993 [1973]. Christelijk geloof. Zevende druk. Nijkerk : Callenbach.

HEYNS, J.A. 1978. Dogmatiek. Pretoria : NG Kerkboekhandel.

DE KLERK, F.W. 1998. The last trek: a new beginning. The autobiography. London : MacMillan.

KRAUS, H.-J. 1975. Reich Gottes: Reich der Freiheit. Grundriss Systematische Theologie. Neukirchen : Neukirchen-Vluyn. 
KUITERT, H.M. 1998. Jezus: nalatenschap van het christendom. Schets voor een christologie. Baarn : Ten Have.

SCHELTENS, W.J.W. \& WENTSEL, B. 1998. Open brief aan alle leden van de Gereformeerde Kerken in Nederland, uitgave van het Confessioneel Gereformeerd Beraad, November 1998. (Verkrijgbaar bij P.J. Schalk, Kooikersweg 360, 5224 AZ 's-Hertogenbosch, tel. 073-62 12 166.)

WENTSEL, B. 1981. Het Woord, de Zoon en de Dienst. Dogmatiek deel 1. Kampen : Kok.

WENTSEL, B. 1982. De openbaring, het verbond en de apriori's. Dogmatiek 2. Kampen : Kok.

WENTSEL, B. 1987. God en mens verzoend: Godsleer, mensleer en zondeleer. Dogmatiek 3A. Kampen : Kok.

WENTSEL, B. 1991. Incarnatie, verzoening, Koninkrijk van God. Dogmatiek 3B. Kampen : Kok.

WENTSEL, B. 1995. De Heilig Geest, de Kerk en de laatste dingen: De persoon en het werk van de Heilige Geest. Dogmatiek 4A. Kampen : Kok.

WENTSEL, B. 1998a. De Kerk als het saamhorige volk Gods. Dogmatiek 4B. Kampen : Kok.

WENTSEL, B. 1998b. De genademiddelen, het gemenebest en het eschaton. Dogmatiek 4C. Kampen : Kok.

VAN WYK, J.H. 1986. Gesindheid en gestalte. Pretoria : NG Kerkboekhandel.

VAN WYK, J.H. 1989. Die Woord is waardevol: 'n Dogmatiese besinning oor die reformatoriese Skrifbeskouing. Potchefstroom : PU vir CHO. 